\title{
Hermeneutiese perspektiewe op geweld in die Nuwe Testament
}

\author{
Pieter G R de Villiers ${ }^{1}$ \\ Fakulteit Teologie \\ Universiteit van die Vrystaat
}

\begin{abstract}
Hermeneutical perspectives on violence in the New Testament

This article discusses hermeneutical perspectives on violence in the New Testament as they appear in articles in this publication and in New Testament Studies in general. It contrasts the traditional perspective on the New Testament as book of peace with the growing insight in its violent nature. It is followed by a discussion of the multi-faceted nature of both notions of peace and violence and the various forms in which they are expressed. After an analysis of the relationship between violence and its alternatives, the various forms of violence are outlined in terms of their relationship to their experiential realities. This is followed by remarks about an adequate methodology for the study of violence, the way in which violence is countered in the New Testament texts and, finally, three possible explanations for the nature of violence.
\end{abstract}

Revelation 18 is perhaps the passage that has most deeply offended the moral sensibilities of readers, Christian and non-Christian alike

(Yarbro Collins 1983:737)

People who have never been persecuted for their faith or vilified, smeared, and imprisoned because of their testimony for Jesus Christ, will have great difficulty understanding these words of John

(Boesak 1987:133)

\section{DIE NUWE TESTAMENT AS BOEK VAN VREDE}

Die gevestigde en gewilde teorie dat die eerste Christene nie-gewelddadig was, grotendeels ondersteun deur uitsprake van bekende vroeg-Christelike skrywers, het groot invloed op die interpretasie van geweld in die Nuwe

\footnotetext{
${ }^{1}$ Hierdie artikel wil na aanleiding van die bydraes elders in hierdie bundel en in die lig van die navorsing oor geweld in die Nuwe Testament, enkele hermeneutiese opmerkings as samevatting, maar ook as moontlike agenda vir verdere navorsing uitspel.
} 
Testament uitgeoefen. Soms word sekere pagane skrywers oor Christene se verset teen oorlog en geweld ook ingespan om 'n bepaalde vredesbeeld van die vroegste Christendom en hul geskrifte te skep. ${ }^{2}$ Bercott (1992:40-2) se opmerking, "The church unequivocally equated war with murder" volg hy byvoorbeeld op met pasifistiese uitsprake van bekende vroeë figure soos Justinus die Martelaar, Tertullianus, Origines, Amobius en Lactantius.

Hierdie siening is onlangs nog in die belangrike werk van Hays oor die morele visie van die Nuwe Testament verdedig. Hy skryf (1996:332) daarin 'n aparte hoofstuk oor geweld as 'n eerste voorbeeld van hoe sy metodologiese voorstelle oor die funksionering van die Nuwe Testament in normatiewe Christelike etiek prakties toegepas kan word. $\mathrm{Na}$ 'n eksegetiese analise van sommige sleuteltekste, veral van Matteus 5:38-48 kom hy tot die slotsom, "Thus, from Matthew to Revelation we find a consistent witness against violence and a calling to community to follow the example of Jesus in accepting suffering rather than inflicting it." Die enigste moontlike uitsondering in die Nuwe Testament op hierdie beeld van 'n vreedsame gemeenskap is die feit dat sommige soldate in die gemeenskap opgeneem en sonder kritiek op hul betrokkenheid by oorlog aanvaar is. Ook die Ou-Testamentiese geweldtekste en sy oproepe tot oorlog kan volgens Hays nie hierdie vredesbeeld aantas nie, want die Nuwe Testament bly normatief en relativeer die Ou-Testamentiese voorstelling met sy siening van 'n barmhartige God en 'n toekomstige vrederyk (Hays 1996:335-7). ${ }^{3}$

Teen hierdie agtergrond is ' $n$ debat oor geweld in die Nuwe Testament van die begin af onder druk - meer nog omdat daar duidelik baie op die spel is. Die vredesiening word deur Hays (1996:314) as 'n wesenlik aspek van die evangelie gesien: "With regard to the issue of violence, the New Testament bears a powerful witness that is both univocal and pervasive, for it is integrally related to the heart of the kerygma and to God's fundamental elective purpose" (vgl verder ook Desjardins 1997:10-1).

\footnotetext{
${ }^{2}$ Bercott (1992:48) verwys bv na Celsus se bespreking van die vroeë Christene se weiering om vir die Romeinse Ryk te veg en Origines se antwoord hierop. Bercott (1992:40), merk darem self op: "Although the New Testament writings leave room for doubt on the subject of Christian participation in war, the same cannot be said of the second- and third-century Christian writings."

${ }^{3}$ Hays (1996:327) verwys kortliks na Psalm 139:21-2 as 'n voorbeeld van die tipe vyandshaat wat Jesus deur sy liefdesgebod vervang, hoewel daar geen Ou-Testamentiese opdrag tot vyandshaat is nie. Hy verreken nie die voorbeelde in die Ou Testament waar haat en uitwissing van die vyand selfs op die wil van God teruggevoer word nie. Carter (2005:97; 99102) wys ook op voorbeelde van geweld in Matteus (bv Jesus se verbale retoriek), al is die dissipels nie-gewelddadig.
} 


\section{BEDENKINGE}

Daar is egter ook 'n ander sy van die saak. Reeds in die tye dat vroeë kerkvaders pasifistiese interpretasies van die Bybel gegee het, was daar tog 'n groep wat besorgd was oor sy gewelddadige karakter (Barr 1998:101-49; Grant 1953). ${ }^{4}$ In vroeë manuskripte soos Codex Sinaiticus verskyn byvoorbeeld minder gewelddadige variante vir sekere verse in Openbaring waardeur oorskrywers hulle argwaan oor problematiese geweldstekste laat blyk het. ${ }^{5}$ Op soortgelyke manier het Oecumenius in die enigste oorblywende Griekse kommentaar op Openbaring in die sesde eeu $\mathrm{n} C$ die goedheid van God se karakter teenoor die hardheid van gewelddadige teksgedeeltes beklemtoon (De Villiers 2007:206-7). Reeds hierdie voorbeelde is genoeg om die kwessie van geweld in die Nuwe Testament as 'n ou probleem uit te wys.

Dit is nietemin veral in onlangse tye dat die gewelddadige karakter van die Nuwe Testament sterk onder die loep gekom het. ${ }^{6}$ Collins (1983:729) het naamlik radeloos oor Openbaring opgemerk hoe moeilik dit is om 'n verklaring te vind vir die konsekwent gewelddadige aanval op Rome, ${ }^{7}$ terwyl Marshall $(2001,2005)$ heelwat later vanuit 'n postkoloniale lees van die teks, Johannes se geweldsuitsprake tot intense groepspanninge binne Joodse geledere tydens die Joodse oorlog (66-70 nC) herlei het. Joodse groepe se hibriditeit as gekolonaliseerdes in die multi-kulturele Romeinse ryk dwing hulle tot selfdefinisie teenoor veral mede-Jode wat volgens hulle hul Joodse identiteit afwater deur oorgawe of samewerking met die Romeine. Die gewelddadige taal van Openbaring is volgens hom gerig teen daardie mede-gelowiges. Terwyl Collins (1983:746-7) wys op die moeilike persoonlike situasie van Johannes en die ekonomiese agterstande wat die gewelddadigheid van die boek kan verklaar, is Marshall van mening dat Johannes veel meer ideologies in sy gewelddadige uitsprake is. Hy huiwer nie om die dwaalweë van ander aan te vat nie. "And the violence with which (he) defends those seemingly absolute convictions is chilling" (Marshall 2005:48).

Selfs waar Openbaring met sagter handskoene hanteer is, het die insigte in die gewelddadige karakter daarvan tog ook deurgeslaan. In 'n resente bundel interkulturele studies oor Openbaring, skryf die redakteur in sy

\footnotetext{
${ }^{4}$ Grant se invloed op die debat oor geweld in Openbaring blyk uit vele verwysings na sy opmerkings in sekondêre literatuur.

${ }^{5}$ Hernandez (2006:92) wys bv op Codex Sinaiticus se versagtende lesing van Openbaring 2:22 ("one of the most violent depictions of the exalted Christ's judgment in the Apocalypse"). Die oorskrywer verander Christus se gewelddadige "gooi" van Jezebel op 'n bed ( $\beta \alpha \dot{\alpha} \lambda \omega \omega)$ na 'n roep to die oordeel ( $k \alpha \lambda \omega \hat{)}$ ). Kyk ook sy konklusies (Hernandez 2006:126-31).

${ }^{6}$ Vir meer motiverings vir die nuwe belangstelling in geweld, kyk De Villiers (2008:213-8).

${ }^{7}$ Collins se artikel bied nog steeds 'n nuttige literatuuroorsig oor die probleem van geweld in Openbaring al is dit hoofsaaklik op besprekings van Openbaring 18 gefokus. Kyk ook Collins (1984:165-76).
} 
inleiding dat die verskillende skrywers van artikels ooreenstem dat Johannes sy lesers oproep om hulle te distansieer van die verdrukkende en uitbuitende dwingelandy van die Romeinse Ryk (vgl Rhoads 2005:19). Daarmee is die beeld geskep van Johannes as 'n heroïese, geweldlose kampvegter vir die vervolgdes, die armes en gemarginaliseerdes teen die imperialistiese Romeinse staat. Tog wys sommige bydraes in die bundel ook die geweld in Johannes se eie denke uit - die beste geïllustreer deur die skerp kritiese bydrae van Pippin (2005) waarin sy die gewelddadigheid van Johannes se vroulike simbole bespreek (kyk verder hieronder).

Ongeveer 'n dekade gelede nog het Desjardins (1997) uitgewys dat die diskussie oor geweld in die Bybel nog nie op dreef gekom het nie. Hy het toe twee bane in die vroeë Christendom uitgewys, naamlik 'n vredesbaan wat steeds nog ter sake is en 'n geweldsbaan wat sterker is as wat dikwels voorgegee word. "The violence-promoting side, though, is equally strong: it also disturbs me, all the more so because I rarely find it discussed in academic and non-academic circles" (Desjardins 1997:121; kursivering toegevoeg; vgl Frankfurter 2005:141 en ook die bydrae van Van Henten in hierdie bundel oor die twee bane).

Sedertdien, veral na die politieke geweldsaksies in verskeie wêrelddele, het die gesprek groter dringendheid gekry en word geweld in die Nuwe Testament in groter mater raakgesien en in meer detail bestudeer.

Teen hierdie tyd en in die lig van die bydraes in hierdie bundel is dit duidelik dat die kwessie van geweld nie meer geïgnoreer of as minder belangrik as net maar nog 'n tema van ondersoek afgemaak kan word nie. Daarvoor het die debat te ver gevorder. Teenoor Hays wat vrede as wesenlik aan die evangelie beskou, het Frankfurter (2005:147) byvoorbeeld daarop gewys hoedat geweld vir sekere godsdienstige groepe 'n hebbery kan word. Hy verwys na die $Q$ uitspraak oor die doodmaak van die profete (Luk 11:4951) en merk op hoedat die preokkupasie met geweld oënskynlik die identiteit van die groep agter die opmerking dra:

But the gruesome details of prophets' blood pouring out... shows that there is more than just distanced reflection on history here. Violence and gore have become not just the subject but the very matrix of meaningful history. The insiders are to experience violence in the present too as the essence of divine action and Jewish self-understanding.

(Frankfurter 2005:147; kursivering toegevoeg)

Hy bevraagteken teorieë wat so 'n preokkupasie as sosiaal gedetermineerd beskou. Ook bevoorregtes kan met geweld behep wees - wat die onderwerp des te meer ter sake maak. Die tragiese is boonop dat sulke hebbery in ander 
en latere kontekste dikwels uitgroei in sistematiese ideologieë van martelaarskap wat dan op 'n stadium in 'n vonk in die kruitvat van weerwraak laat ontbrand (Frankfurter 2005:148). Martelaarskap, gedra deur geweldstaal, het op die manier vernietigende potensiaal (kyk ook verder hieronder). Self op hierdie vlak al, word die dringendheid van die debat onderstreep.

Uit die groeiende literatuur en kritiese vrae blyk dit dat die tema van geweld waarskynlik in die volgende dekades die grootste uitdaging vir die handhawing van 'n etiese karakter van die Bybelse en teologiese diskoers gaan bied. Met die herkenning van die omvang en aard van die probleem, is die belangrike stap tot ' $n$ behoorlike debat oor die probleem van geweld in Bybelse tektste geneem.

\section{VORME VAN GEWELD}

Die siening van die Nuwe Testament as 'n boek van beide geweld en vrede word tans verder genuanseer, soos blyk uit die aandaag aan die vorme daarvan.

\subsection{Fisieke geweld}

Dat veral fisieke geweld in Bybelse tekste algaande onder die loep geneem is, moet nie onderskat word nie. Dit was ongewoond in antieke en moderne samelewingskontekste waarin geweld, veral as oorlogsgeweld, meestal as teken van heldemoed en dapperheid verheerlik is en vrees vir geweld as lafhartig of 'n swakheid beskou is (Van der Dennenn 1978). Die literatuur, kuns, argitektuur en poësie van selfs die mees ontwikkelde lande bevat vele voorbeelde van die vaste, onaantasbare en alomteenwoordige rol van geweld. Die vervolging van die sogenaamde pasifistiese vredeskerke en die gewilde sogenaamde regverdige oorlog teorie wys hoe beperk enige bevraagtekening van selfs fisieke geweld sou wees.

In hierdie konteks is die debat oor fisieke geweld van groter betekenis as wat normaalweg gedink word. Algaande moet die debat gesanksioneerde en gevestigde gebruike soos die doodstraf bevraagteken, maar ook hoogs emosionele vraagstukke soos aborsie of klaarblyklik minder ekstreme kwessies soos die fisieke straf van kinders in die onderwys en gesin raak. Terwyl Van Henten in sy bydrae tot die bundel uitwys hoe fisieke geweld in Nederland eenvoudig met verloop van tyd onaanvaarbaar geword het, toon Kotze se skrywe oor Augustinus se hoogs emosionele reaksie op lyfstraf hoe kindergemoedere van alle tye 'n skynbare normale samelewingspraktyk as ekstreem kan beleef. Die feit dat sy vanuit so 'n hoek haar artikel kon aanbied, reflekteer reeds die sensitiwiteit vir fisieke geweld in 'n opvoedingskonteks. Van Eck se bydrae laat die leser ook ontnugterd terugsit by die skielike besef 
hoe vanselfsprekend die Gelykenis van die Boere en die Wingerd ekstreem fisieke geweld gebruik om 'n teologiese punt te maak (Mark 12:1-12). Die gesprek oor fisieke geweld gaan dus uiteindelik om veel meer as oorlogvoering. Dit raak ook 'n velerlei van sosio-kulturele kwessies en het op verskeie vlakke (soms selfs dramatiese) etiese implikasies.

\subsection{Ander vorme van geweld}

Die bydraes in hierdie bundel en resente navorsing wys egter voorts hoe die gesprek oor geweld nie meer oor die kwessie van blote fisieke geweld gaan nie. Dit is opvallend hoe dikwels in hierdie bundel nie-fisieke vorme van geweld onder die loep geneem is. Van Henten het in sy artikel 'n definisie van geweld gegee waarin hy na aanleiding van bestaande Nuwe-Testamentiese navorsing verskeie vorme van geweld lys. Sy nouer siening verklaar geweld as 'n fisieke daad of as 'n daad wat iemand se menslikheid ("personhood") skade aandoen. In 'n ruimer definisie beteken geweld 'n dwangmatige handeling teenoor ander. 'n Definisie bepaal die debat wesenlik deurdat 'n ruimer siening meer gewelddadige aspekte in tekste uitwys, maar in die algemeen is dit duidelik dat die gesprek lank nie meer net oor fisieke geweld gaan nie.

Die meeste skrywers in hierdie bundel het Van Henten insigte bevestig deur ook 'n ruimer opvatiing van geweld te volg. Nuwe dimensies is so na vore gebring. Dit blyk byvoorbeeld uit die artikels oor Galasiërs en Johannes as ekstreme voorbeelde van verbale geweld. In soortgelyke sin is ook politieke, ekonomiese en strukturele geweld (bv patriargalisme) telkens uitgewys (kyk ook die volgende paragraaf), waarmee belangrike tendense in die navorsing bevestig word (vgl bv die bydraes van Van Eck en Punt, asook verder Boesak 1987:108-25; Bauckham 1993:338-83 en Pippen \& Aichele 1998:7) ${ }^{8}$. Vroulike lesers soos Pippin (2005) met haar ervaring van die posisie van die vrou in 'n gevorderde samelewing soos die Verenigde State skryf byvoorbeeld (Pippin 2005:144), "The Christian Apocalypse of John is limited in its destruction of the forces of oppression. The irony of the grotesque burning of the Whore is that the Christian utopia itself is an oppressive world (for women)." Carter (2005:97) wys dat geweld steeds weer benoem moet word wanneer hy in sy studie van Matteus waarsku dat geweld nie te maklik met gender en klas verbind moet word nie. Volgens hom is daar in Matteus 10 sprake van gesinsgeweld waar dorpsgesinne in vyandskap teenoor mekaar leef.

\footnotetext{
${ }^{8}$ Pippen en Aichele (1998:7) skryf dat geweld in die Bybel nie net fisieke, geestelike of godsdienstige vorme aanneem nie, maar dikwels verbale geweld behels "which disfigures, dehumanizes, or erases altogether the human as object and as subject."
} 


\subsection{Agentskap van geweld}

In lyn hiermee het daar ook 'n ander belangrike verskuiwing in die navorsing plaasgevind, wat ook in hierdie bundel gereflekteer word. Geweld wissel ook in vorm na gelang van die perpetreerders daarvan. Dit is daarom nodig om te let op wié die geweldplegers is. Agentskap verwys nie net na persone nie, maar kan ook onpersoonlik wys op samelewingstrukture wat as gewelddadig ervaar word.

Hierdie perspektief op agentskap is veral van belang ten opsigte van Bybeltekste. Terwyl vroeë Christene, histories gesproke, ongetwyfeld gewelddadige optrede ervaar het,is die tradisionele siening van 'n vervolgde, onskuldige groepie Christene nie meer die stand van sake in die navorsing nie. Die interpretasie van die Nuwe Testament is dikwels gekontamineer deur 'n slagoffer-sindroom waarmee die tradisionele martelaarskap van die vroegste Christene benader is. Hoe problematies martelaarskap was blyk uit verskeie vroeg-Christelike geskrifte se kritiese bespreking van martelaarskap. Hulle was veral met argwaan gevul oor self-gesentreerde martelaarskap en het dit as oneg afgewys.

Verskeie teksanalises in hierdie bundel toon dat terwyl Christene deur pagane en Joodse partye vervolg word, hulle self ook geweldenaars was. Jesus was nie net voorwerp van geweld nie, maar word self met verbale geweld verbind (Matt 23; kyk Van Eck en Van der Watt / Kok se bydraes). Ook God is 'n agent van geweld - en dan selfs op die basiese vlak van fisieke geweld.

In die kwessie van agentskap en die aktiewe rol van Christene in die perpetrering van geweld, speel die resepsie-geskiedenis van die Nuwe Testament ' $n$ belangrike rol. Die artikel van Nicklas in hierdie bundel oor die anti-Semitiese interpretasie en die geweld wat dit uitgelok het, is in die opsig van buitengewone belang. Die Nuwe Testament is nie 'n onskuldig eiland van vrede binne 'n oseaan vol geweld nie. Dit ontmasker Christene as geweldenaars, maar dit het ook die potensiaal om as teks en as voorwerp van navorsing ekstreme vorme van geweld te ontsteek. Nicklas se artikel toon die ontstellende en tragiese gevolge van 'n onetiese wetenskapsbeoefening. Die diskussie oor geweld in die vakgebied is so belangrik omdat dit uitwys hoe geweld selfs in die hoë howe van wetenskaplike werk insypel en selfs daardeur gegenereer word. Nie net die karakters in die tekste of die tekste self nie, maar ook die navorsing oor die tekste word dan agente van geweld.

\subsection{Verborge vorme van geweld}

Terwyl dit nuttig bly om voortdurend vorme van geweld te benoem sodat ' $n$ teks omvattend na sy geweldskarakter bevra kan word, bly daar dikwels instellinge, persone, opvattinge en strukture wat slegs by nadere besinning as gewelddadige herken word - dikwels omdat hulle origens so fatsoenlik en 
hoofstroom in karakter is, maar ook omdat lesers en navorsers se ervaringswêrelde nuwe dimensies van geweld ontsluit. In hierdie bundel en in bespreking oor geweld word gewoonlik (en maklik) gepraat oor geweld wat maklik en met algemene instemming herken kan word. Tog is daar vorme van geweld of sake wat geweld kan uitlok, wat minder vanselfsprekend is en wat moeilik bloot vanuit ervaringe of in terme van bekende vorme daarvan herken kan word.

Dit is veral hermeneutiese besinninge wat profiel aan sulke onontginde of verborge vorme van geweld gee. Voorbeelde hiervan is uitgewys in die werk van Schwartz (1997) wat, soos Van Henten in sy bydrae tot die bundel uitwys, geweld verrassenderwyse met monoteïsme verbind. Collins (2003) weer herlei dit na irrasionele, fundamentalistiese sekerheid en Lüdemann (1998) verbind geweld uiteindelik met 'n uitverkorenheidsbewussyn. ${ }^{9}$ Die bydrae van Botha in hierdie bundel staan ook in die teken van hierdie dieper delf na dikwels verwaarloosde of onherkende vorme van geweld. Onder verskeie van sy opmerkings, is die verwysing na die kommodifisering van geweld besonder interessant en indikatief van moontlikhede vir verdere ondersoek. ${ }^{10}$ Hulle analises gee almal illustrasies van besinning wat dieper loop as bloot eksegetiese of historiese kwessies en wat op kreatiewe maniere skynbaar onskuldige geloofskwessies as potensieel gewelddadig uitwys. ${ }^{11}$ Daarmee word die tradisionele Bybelwetenskappe en, op 'n wyer vlak, die teologie gekonfronteer met die ongemaklike uitdaging om die impak van gevestigde en selfs wesenlike aspekte van hul eie doenigheid te bedink. Hierdie werk staan egter in die verlengde van 'n hermeneutiek van suspisie en is in lyn met 'n oop, self-kritiese wetenskapsbeoefening.

\footnotetext{
${ }^{9}$ Desjardins (1997:90) merk byvoorbeeld ook op dat die bekende apokaliptiese perspektief in die Nuwe Testament "in particular its portrayal of God and Jesus as wrathful warriors, leads to the devaluation of the present world and a division of humanity into groups of 'saved' and 'damned."' Terwyl 'n escapisme en 'n stereotipering inderdaad problematies kon wees, moet onthou word dat Openbaring nie die wêreld devalueer nie. Daarvoor is hy te Joods in sy agtergrond en speel die skepping te groot rol in sy denke. Ook relativeer hy iewers wel die sterk dualisme met sy opmerkings oor die bekering van die nasies - nie net in die eindtyd nie, maar ook bv in Openbaring 11:13.

${ }^{10}$ Nadenke hieroor, vanuit 'n kontemporêre perspektief binne verbruikersgemeenskappe, sou moontlike raaklyne met die Romeinse imperiale diskoers kon oplewer, terwyl dit ook nuttiglik ontgin sou kon word om krities te vra na probleme van 'n moontlike anakronistiese lees van antieke tekste soos die Bybel.

${ }^{11}$ Vgl egter Johnson (1999) en Kaminsky (2003) vir sinvolle kritiek op sommige van hierdie standpunte. Kaminsky (2003) skryf: "Just as it is quite dubious that monotheism and exclusivism can be linked causally to violence, it is questionable to link absolutism and certitude to violence. There is a misplaced bias against fanaticism that links the idea of fanaticism to evil. Fanaticism can be directed towards human good; in fact, many of the world's greatest religious figures rightly could be called fanatics. The single-minded dedication to a cause that is associated with fanaticism can produce an Osama Bin Laden, but it has also produced Mother Teresa."
} 
Watter werk op die terrein nog wag en hoe verskuild dwangmatige strukture kan wees, is op provokatiewe manier uitgewerk deur Boer (1998) in 'n bespreking wat gestuur word deur 'n duidelike postmoderne en materialistiese ideologiese onderbou. Daarin wys hy hoe die karnavaleske en anargistiese optrede van profete ${ }^{12}$ met hul utopiese denke deur'n hegemoniese diskoers tot ' $n$ vaal middelmatigheid ontkragtig kan word. ${ }^{13}$ "Hegemony is, then, the dominant ideological structure in a given society, the exercise of power without direct violence" (Boer 1998:40; kursivering toegevoeg). Só 'n struktuur het in die geskiedenis van die Christendom volgens hom die ekstatiese profetisme onder bedwang gebring deur dit beide te legitimeer en te delegitimeer. Profesie word byvoorbeeld as 'n sub-kultuur verdra, selfs aanvaar, maar dan alleen binne die perke wat die hegemoniese diskoers neerlê. Sodra die perke oorskry word, gryp die hegemonie deur sensuur in. Profetiese denke word voorts ook gekoöpteer deur dit in die kanon op te neem. Op die manier word die radikaliteit van die profete omgebuig in 'n tandelose middelmatigheid, gebruik deur "largely middle class, elderly and conservative churches, who practice a liberal, hand-wringing, approach to social justice that incorporates the prophets among their central texts"! (Boer 1998:42). Boer verwys na Gramsci se tese dat ' $n$ hegemonie nooit uitgewoed kom nie en steeds met ' $n$ frenetiese krasheid homself wil bly vestig. Die opvallende van 'n hegemonie is dat, terwyl dit self gewelddadig is, dit die indruk skep dat dit gewelddadigheid uitgewis het. In werklikheid het dit sy eie geweld weggesteek met die voorwendsel dat dit geweld uitgeskakel het. Vir Boer (1998:44) kan die geweld van die hegemonie slegs deur politieke geweld uitgeskakel word. Vir hom verteenwoordig Esegiël as profeet, ten spyte van sy gender geweld (wat vir hom so onwenslik is soos rasse en seksuele geweld), egter nou 'n vorm van gewenste politieke geweld waarmee die verborge geweld van die hegemonie deurbreek kan word. Politieke geweld

.... may, unfortunately, be required in the light of the implications of hegemony with violence, hegemony being the originary and usurping violence of a social structure whose violent character has been effaced. Indeed, As Žižek argues, the highest form of violence is that which coincides with the absence of violence, that is, this supreme violence "determines the 'specific colour' of the very horizon within which something is to be perceived as violence".

(Boer 1994:204)

\footnotetext{
${ }^{12}$ Hy verwys veral na Esegiël en plaas hom (1998:35) binne die debat wat die geïmpliseerde skrywer van die boek beskou as geestelik versteurd indien nie skisofrenies nie en misogenie. ${ }^{13}$ Van Aarde verwys in sy bydrae in hierdie bundel ook met insig na die problematiese van 'n
hegemonie.
} 
In taal wat herinner aan die simboliese teks van Openbaring, kom hy tot die slotsom:

And this is where the daring suggestion of Jan Tarlin (1997) finds its place: he argues that in the very pornography (which he understands at the conjunction of sexual representation and violence) of Ezekiel's texts may be found a utopian glimpse that breaks the hegemonic shell. It is then a sad reflection on our own situation - and it seems of Ezekiel's texts - that the strength of the originary, hegemonic, violence requires something like Ezekiel or Axl Rose to offer the possibility that it may be broken.

(Boer 1998:42)

Vanuit die hegemonie in die Bybelwetenskappe, sou 'n mens hierdie perspektief as provokatief kon beoordeel, maar dit dan tog dieper bedink (selfs op gevaar van die verwyt van ko-optering) met die oog op helderheid oor die implikasies daarvan: wanneer is die afwesigheid van geweld of die pleit vir nie-gewelddadigheid 'n pretensie waaragter daar gewelddadige, selfs moorddadige aansprake skuil? Is daar meer fundamentele vorme van geweld wat sterker, selfs gewelddadige, opposisie vra as minder fundamentele vorme? Is daar in profetiese utopieë soos dié van Esegiël en Openbaring die moontlikheid van 'n vorm van geweld wat die enigste uitweg is uit 'n verknegtende en gewelddadige hegemonie? (Vgl afd 7.2 hier onder.) Is Boesak $^{14}$ nader aan "die waarheid" as Collins (vgl die motto's van hierdie artikel)? Bring só 'n siening van geweld ons terug by die teorie van die regverdige oorlog wat deesdae toenemend verfoei word, maar dan net in 'n kontra-kulturele, anti-establishment gewaad? ${ }^{15}$

\section{ERVARING VAN GEWELD}

Die verskillende vorme van geweld hang ten nouste saam met die ervaringswêrelde waarin hulle geanker is. Terwyl definisies met hul modernistiese aard ${ }^{16}$ en hul "objektiewe" kenmerke van geweld, navorsing

\footnotetext{
${ }^{14}$ Kyk die bespreking hierbo. Boesak (1987:109) skryf ook dat die vraag in Openbaring 15:4 ("Wie sal U nie vrees nie, Here?") word nie gestel in die stil afgesonderdheid van intellektuele nadenke nie, maar te midde van die gewelddadige, angstige woede van die uitbuitende en vernietigende magte.

${ }^{15}$ Kyk ook die belangrike opmerkings van Van Aarde in sy bydrae tot hierdie bundel en die verwysing in sy tweede voetnoot na die werk van Vledder.

${ }^{16}$ Carter (2005:90) merk op hoe die perseptuele karakter van geweld geïllustreer word deur die talle pogings om 'n definisie daarvan vas te stel. "The discussion is complex, diverse, and invested. Violence often exists or does not exist in the eye of the politically committed beholder." Dit is veral die begrip "invested" wat hier veelseggend is. Kompeterende persepsies sal immers steeds op legitimiteit wil aanspraak maak.
} 
kan inperk of selfs soms mislei, help Ricoeur se hermeneutiese insigte aangaande die versmelting van die horisonne van teks en leser om die gesprek oor vorme van geweld oop te hou en om die evaluering van geweldstekste met integriteit te doen. Geweld hang ten nouste saam, in terme van Ricoeur se denke, met die versmelting van tekste se horison met die gesigseinder van die leser. Sonder dat dit noodwendig altyd op relativering hoef te wys, asof geweld vir die een nie geweld vir die ander hoef te wees nie, help hierdie insig om reg te laat geskied aan die ervaringswêrelde waarin die skryf en lees van tekste veranker is. Die ervaringswêreld het te doen met ten minste twee aspekte - die ervaring in en die ervaring van geweldstektste.

\subsection{Ervaring in geweldstekste}

Desjardins (1997:66-70) het geredeneer dat geweld in die Nuwe Testament in die algemeen toegeskryf moet word aan die frustrasie van die eerste Christene oor die stadige vordering wat hulle gemaak het. Hulle moes toesien hoe hul leier verdag gemaak word, terwyl hul opponente wat sy dood veroorsaak het, se destruktiewe mag ongehinderd voortduur. Hy (1997:69) beoordeel byvoorbeeld Matteus se haatspraak teen die Jode met ' $n$ vernietigende $\sin$ ("The only redeeming factor to these verses [Matt 27:24-25 as bron vir anti-Semitisme - PdeV] is that the author himself was Jewish," maar laat volg kort daarna (1997:70), "The tone, then, is understandable, given the historical context, but the violence remains.") Hier word die geweld vanuit die ervaringskonteks belig en in terme daarvan verstaanbaar gemaak.

Frankfurter ontwikkel die perspektief nog verder deur daarop te wys hoe geweld verskillend lyk as gevolg van die pogings van gelowiges om uitdrukking aan hul self-identiteit te gee.

Jesus-focused identity ... could be constructed along various axes halakic, as in Revelation,; political as in Matthew; or cosmic/ anthropological, as in John. That is, legends of violence allowed a subset of Jews to feel different from other Jews by virtue of imagining themselves persecuted by those other Jews. Intriguingly, these insiders could construe their intimate enemies from within Jewishness, as in Matthew or Revelation (or Paul in Galatians 1), or they could relegate the term loudaios entirely to the enemy, as in John. No doubt there were regional and historical factors as well as social dynamics that contribute to these various polarities in selfdefinition.

(Frankfurter 2005:142; kursivering toegevoeg)

Hierdie insigte moet geplaas word binne die toenemend kritiek in resente navorsing teen naïef-realistiese pogings tot kontekstualiteit. In die geval van 
Openbaring is in onlangse navorsing (bv Thompson 1990) sterk kritiek gelewer op gevestigde pogings om die boek as 'n reaksie op 'n amptelike Romeinse vervolging van Christene te lees. ${ }^{17}$ Eerder as om Openbaring vanuit 'n sosio-historiese konteks te verklaar, benader Thompson die teks vanuit die kennis-sosiologie in terme van kognitiewe strukture. Dit beteken dat die diskoers van Johannes se minderheidsgroep langs die dominante Romeinse diskoers geplaas word. Ervaring wys dat minderheidsgroepe sterk reageer, selfs gewelddadig, ${ }^{18}$ teen hulle marginalisering aan die hand van 'n dominante groep. Sulke kleiner groepe produseer tekste gedra deur 'n simboliese universum wat alleen verstaan kan word wanneer dit met al sy verskillende aspekte teenoor die kontrasterende simboliese universum geplaas word. Geweld in Openbaring kan dus nie op 'n naief-realistiese manier uit vervolgingsaksies deur die Romeine verklaar word nie, maar is deel van 'n veel groter groepservaring wat funksioneer binne 'n sosiale kennissisteem en wat kompeteer met verwante groepservaringe.

Dieselfde insigte geld vir ander Nuwe-Testamentiese boeke. Op 'n soortgelyke manier as Thompson, het Carter (2005) Matteus en die geweldsuitsprake daarin in 'n breër verband geplaas. Hy plaas Matteus se diskoers byvoorbeeld binne die breër raamwerk van die kompeterende Joodse (Jerusalem) en Romeinse diskoerse. Matteus se geweldstaal is die gevolg van die oorvleueling van sy diskoers met sy imperiale konteks. Hy skryf,

Matthew' Gospel thus constructs violence theologically. It regards it as central to the sinful human societal situation from which Jesus is to save people (1:21); as deeply enmeshed in and expressed by the current elite-dominated, imperial, societal structure; as

\footnotetext{
${ }^{17}$ Volgens Thompson (1990:174-85) skryf Johannes oor vervolging omdat dit `n topos in sy apokaliptiese genre was en nie omdat dit noodwendig ' $n$ historiese realiteit in sy tyd was nie. Daarmee bedoel hy nie dat Christene nie vervolg is nie (Thompson 1990:190-1). Hy wys trouens op die gevaarlike situasie waarin Christene hulself bevind en skryf op ' $\mathrm{n}$ genuanseerde manier oor die multi-dimensionele karakter van die verdrukking waarin gelowiges hulle bevind het. Johannes wil met hierdie genre egter dieper as vervolging en geweld afsteek ("the deep structures of reality that enfolds all historical disclosures") en veral 'n alternatiewe opsie op die status quo aanbied, ruimte skep vir kritiek op die openbare orde en die egte betekenis van menslike lewe uitwys. Kyk veral Thompson se positiewe samevatting oor Johannes se alternatiewe diskoers op die politieke diskoers van sy tyd (1990:197; 200-1). Knight (1999:29), in 'n minder genuanseerde oorname van Thompson se insigte, meen Openbaring reflekteer ' $n$ problematiese sektariese denke. Hy haal dan vir Baur aan oor Johannes as 'n buitengewoon verwarde skrywer wie se hutspot van Joodse, Christelike en ander mitologiese elemente skaars van intellektuele en geestelike diepte getuig.

${ }^{18}$ Thompson (1990:193) skryf bv. die minderheidsgroep kan "intense and excessively hostile" reageer as hulle waarheidsaansprake afgemaak word deur die dominante groep.
} 
inevitable to the conflict over the competing societal visions that come into sharp collision through Jesus' life and death; and as crucial to the divine completion of that salvation in Jesus' return and resultant judgment. In resisting and redeeming violence of the imperial status quo, the gospel also affirms that some violence, namely the violence of God, the supreme ruler who is "lord of heaven and earth (11:25), and of God's agent Jesus, is legitimate and necessary."

(Carter 2005:102)

Vir Carter is Matteus se evangelie in die eerste plek 'n teologiese konstruksie. Wanneer Matteus oor geweld praat, wil hy deur sy diskoers 'n teologiese punt teenoor die heersende diskoers van sy tyd maak.

\begin{abstract}
Violence is not just a means of coercion in the service of greed or power or furthering elite interests, though it is indeed that. The gospel discloses/constructs it to be an activity of the devil, an activity that rejects the gospel of God's empire when and as it affects the present way of life (so 11:23; 10:22; 24:9...). The particular, though not exclusive, penchant for violence among male elites suggests that power groups in a partriarchal and vertical society find the announcement of God's purposes, whether proclaimed by prophets, by Jesus, or by disciples, to be especially disturbing or threatening to the status quo and their self-interest. Household members are also threatened. Violence is constructed as the way of the world. Significantly, it is the gospel that provides the perspective that unmasks the true cosmic and theological nature of the social-political-religious violence.
\end{abstract}

(Carter 2005:98)

Horsley (2005:74-5) plaas op soortgelyke wyse Jesus ook in die konteks van die destruktiewe gevolge van die Romeinse imperialisme. Deur sy uitdrywing van demone is Jesus deel van die intense gewelddadige stryd tussen God en die demoniese geestelike magte, maar hierdie stryd het praktiese, konkrete gevolge. Hy wil verbondsgemeenskappe ${ }^{19}$ in die plattelandse Galilea genees van self-vernietigende sosiale gedrag en die dorpsgemeenskappe laat herleef. Jesus voorsien dat God op die punt gestaan het om die instellinge van die Romeinse Ryk te vernietig. Hoewel Jesus duidelik nie 'n politieke volksrebellie wou inisieer nie, is sy profetiese handelinge gerig op 'n herstel

\footnotetext{
${ }^{19}$ Horsley (2005:70) beklemtoon die verbondskarakter van Jesus se uitsprake in $Q$ wat steun op Eksodus 20:1-17 en Josua 24 as belangrike verbondstekste. Verbondspatrone is steeds behou, maar in kontemporêre Joodse groepe (soos Qumran) in fundamentele, konstitutiewe gemeenskapsvorm en seremonie getransformeer.
} 
van die volk Israel teen die tempel-establishment ${ }^{20}$ en die Romeinse imperialisme.

Die diskoerse van Matteus en Openbaring kontrasteer dus met die alternatiewe Joodse en Romeinse diskoerse van hul tyd. Om die Nuwe Testament te verstaan, moet dit dus nie op 'n naïef-realistiese manier met vermeende historiese realia verbind word nie, maar eerder vanuit 'n diskursiewe of konstruktivistiese perspektief gelees word - soos op 'n konsekwente manier na vore kom in die interessante artikel van Botha in hierdie bundel. Dit is veral nodig in die geval van antieke tekste waarvan die kontekste nie meer empiries toeganklik is nie.

\subsection{Ervaring van geweldstekste}

Maar op 'n tweede vlak word die verskillende vorme van geweld ook ten nouste bepaal deur die kontekste waarin Bybelse tekste geresepteer word. Die arm, stemlose Suid-Afrikaner staan byvoorbeeld nader aan Boesak se resepsie van Openbaring as die kritiese pasifis in 'n eerste wêreld konteks. Maar die versmelting van horisonne kan selfs binne 'n kontinent of land wyd uiteenloop. Yeo (2005:201) skryf byvoorbeeld:

First, Chinese Christians have seen Revelation as a source of hope and empowerment in the face of persecution by the state during the Cultural Revolution. Second, some Chinese Christians have resisted the thorough-going dualism of Revelation regarding "church and state," because such a negative view of the state has polarized Chinese Christianity and has prevented productive cooperation with the state. Third, other Christians like myself, have found Revelation helpful in situations where there is no active persecution of political oppression .... Revelation presents a vision of wholeness and meaning to Chinese people today who are searching for meaning in life and who are neither persecuted nor oppressed.

Hierdie opmerking toon die vormende rol van resepsie en die leser in interpretasie van die Bybel. Dieselfde Bybelse teks kan soms bevrydend werk, terwyl dit vir die bure of vir die volgende geslag problematies word. Of, soos

\footnotetext{
${ }^{20}$ Vir Horsley (2005:73) lewer Jesus in Markus, wat hy pre-70 dateer, met sy tempelaksie baie meer as net 'n "suiwering" daarvan. In navolging van Jeremia veroordeel hy die establishment vir hul uitbuiting van die armes en voorsien hy die totale vernietiging van die tempel. Opvallend skryf Horsley (2005:73), "Jesus' forcible overturning of the tables of the money-changers - the kind of demonstration that would surely be condemned by the ecclesial, university, or political authorities today as 'violent' - prefigures God's judgment of the whole temple system."
} 
vroeër aangewys is, terwyl Openbaring vir sommige politieke bevryding uitwys, bly dit vir ander weer 'n boek wat vroue se status ondermyn.

'n Sleutelbegrip in verband met geweld is "ervaringswêreld". Geweld is in die eerste instansie iets wat deur iemand as geweld "ervaar" word. Dit beteken dat geweld nie alleen maar aan objektiewe, afgeslote kenmerke of in terme van 'n historiese gegewe op 'n naïef realistiese manier gemeet kan word nie. Frankfurter (2005:144) het byvoorbeeld daarop gewys dat gewelddadigheid dikwels nie 'n objektiewe oorsaak het nie, maar weens die vroeë Christene se minderheidsituasie 'n retoriese en sosiologies dinamiek weerspieël wat spesifieke historiese omstandighede transendeer. "It would seem that sectarian movements have the capacity to imagine themselves persecuted even in largely peaceful times and among various economic strata - to erupt in fear and vengeance over what to observers might be the smallest indignities" (Frankfurter 204:144). ${ }^{21}$

\subsection{Legitieme en illegitieme ervaringe}

$\mathrm{Na}$ aanleiding van die opmerking van Yeo wat hierbo aangehaal is, ontstaan die vraag of die teks werklik sulke uiteenlopende en selfs teenoorgestelde ervarings legitimeer. Sommige navorsers redeneer dat 'n skrywer deur sy retoriese tegnieke bepaalde ervaringe aan sy lesers kommunikeer en dus ook ander by implikasie afsny. Schüssler-Fiorenza (1986:124-5) verwerp as voorbeeld die menigte historiese verklarings van die volgelinge van die Lam in Openbaring 14:1-5 en wys op die baie teenstrydige verklarings van die simbool van die 144000 (bv as Joodse Christene, as uitverkore Christene, as manlike Christen askete, as die oorblyfsel van Israel en nog baie ander). Openbaring wil deur sy evokatiewe simbole lesers help om betekenis te skep in hul situasie van vervolging en moontlike martelaarskap. Lesers word ondersteun om die destruktiewe gevolge van hulle situasie van vervreemding te oorkom en hulle vrees te bowe te kom. Volgens haar (1986:142) kan die teks boonop slegs adekwaat verstaan word wanneer die die retoriese situasie van die kontemporêre leser pas op die teks s'n (vgl verder De Villiers 2003). In 'n ander konteks sou Boesak (1987:133) vanuit sy ervaring van 'n onderdrukkende en absolute sisteem van rassisme, in sy kommentaar op Openbaring 18 dieselfde gedagte op sy eie manier verwoord: "People who have never been persecuted for their faith or vilified, smeared, and imprisoned because of their testimony for Jesus Christ, will have great difficulty understanding these words of John" (Boesak 1987:133).

\footnotetext{
21 'n "Definisie" van geweld is in die Bybelwetenskappe nog te veel benadeel deur die gebrek aan interdissiplinêre gesprekke. Dit sal bv ook nodig word om aandag te gee aan Nietzsche se siening van die rede self as gewelddadig. Kyk bv Volf (1996:295). Nicklas se bydrae in hierdie bundel is indirek 'n illustrasie van hoe gewelddadig rasionele wetenskap kan word.
} 
Indien 'n diskursiewe analise 'n naïef-realisme vervang, hou dit heelwat implikasies in. Die perspektiwiese dimensie anker geweld in die groter simboliese universum van die vroeë Christene, wat duidelik ook vredesperspektiewe ingesluit het (kyk hieronder). Hierdie twee aspekte staan in 'n bepaalde verhouding tot mekaar en beïnvloed mekaar wedersyds. Die opstandingservaring van die aanbreek van God se vrederyk moes ook vroegChristene se worsteling met die kwessie van geweld beïnvloed. Om, soos Frankfurter hierbo doen, veral gefrustreerde identiteitsvorming as beslissend vir Christelike minderheidsgroepe te sien, hou nie rekening met sulke groter kompleksiteite wat ook' $n$ rol kon speel in hul houding teenoor geweld nie. ${ }^{22}$ Hier moet byvoorbeeld die wisselwerking tussen identiteitsvorming en geloofsinhoude verreken word. Verheyden se analise toon duidelik hoe Jesus se geweldloosheid deurslaggewend in die perikoop oor die owerspelige vrou is, terwyl Van Houwelingen se opmerkings oor Paulus se transformasie weg van geweld ook tendense blootlê of ondersteun (kyk verder 6.2 en 6.4 hier onder). Ook die latere nie-gewelddadige resepsie van vroeë Christene wys dat hoe die geweldstrajek deur bepaalde oortuigings, insigte en tradisies gekleur is. Hoe geweld dus 'n resultaat is van ervaringe van groepe in hul identiteitsformasie, word hulle ook deur hul gesamentlike tradisies en deur hul oorsprongsgebeure gevorm, soos Johnson (1999) ook tereg uitwys. Dat geweldsuitsprake in 'n diskoers ingemessel is en dat so 'n diskoers uiteenlopende simbole insluit, roep dus die vraag op hoe geweld met sulke ander simbole (soos bv vrede) in verhouding staan en daardeur bepaal word (kyk verder hier onder). Uiteraard is dit ' $n$ vraag wat in elk van die verskillende Bybelboeke op 'n eie manier beantwoord sal word.

\section{METODOLOGIE}

Die vraag is verder nou of die implikasies van geweld as 'n multi-dimensionele kwessie in die navorsing metodologies genoegsaam verreken word. Omdat daar verskeie vorme van geweld is en omdat al die vorme in een teks teenwoordig kan wees (kyk hieroor verder hieronder), vra 'n adekwate teksuitleg dat dit metodologies verantwoord uitgewys sal word. ' $n$ Goeie voorbeeld van só 'n metode van teks-analise is te vind by Carter (2005:86-90). Hy stel op 'n sistematiese manier lang tabelle op waarin hy Matteus se verwysings na geweld in terme van agente, soorte geweld en voorwerpe van geweld naas die betrokke tekste uitlig. Die nut van só 'n gekontroleerde teks-analise is duidelik by die lees van sy artikel. Sy voorlopige lys bied ontstellende materiaal, met verwysings na geweld deur die elite, deur imperiale magte (geïniseer en veroordeel), sinagoges, groepe, dorpe, huishoudings, dissipels, Satan, Jesus, God en vyande van God en die dissipels. Terwyl sy benadering

\footnotetext{
22 Johnson (1999:s I) het tereg uitgewys dat "the Bible may be dealing with experiences of a reality inaccessible to social-scientific reduction, may be grappling with truths more elusive and compelling than 'identity formation', may indeed be revealing a world both more capacious and gracious than that of academic utopias".
} 
hoofsaaklik empiries is, berus dit tog op teoretiese insigte (bv agentskap) wat verder uitgeklaar sal moet word. Die belangrike is egter dat ' $n$ teks sistematies en georganiseerd gelees behoort te word, veral om 'n eklektiese benadering te vermy (vgl ook hier die noukeurige lees van Galasiërs deur Tollmie in hierdie bundel).

\section{ALTERNATIEWE OP GEWELD}

Uit bogenoemde opmerkings het dit indirek al duidelik geword hoe geweld in die groter verbande waarin dit pas en veral die teenpole waarmee dit kontrasteer, bedink behoort te word.

\subsection{Vredesmotiewe}

Geweld word deur 'n reeks van begrippe uitgedruk (soos bv oorlog voer, moord, vervolg en baie ander), maar word ook deur die alternatiewe en teenpole daarvan belig (soos vrede, mag, nie-gewelddadigheid, paradys en baie ander). In vele opsigte word vrede as kontras vir geweld opgestel. Die voorstelling van Jesus as vredesgesant en van God se vredesryk vir die eindtyd kom na vore in sulke motiewe soos die paradys (bv Luk 23:43; Op 2:7), die hemel en die Nuwe Jerusalem (Op 21; ook bv Luk 6:23; 2 Kor 5:1), die Messiaanse vredesryk (bv Luk 2:14), die programmatiese vyandsliefde (Luk 5:9; 6:27-36), die opstanding as heilstyd (vgl Jesus se vredesgroet in Joh 20:21; ook Hand 3:19-21) en die Pauliniese se noue verbintenis van versoening met vrede (bv Rom 5:1). Behalwe vir hierdie vredesperspektief word gelowiges uitgebeeld as getuies wat eerder sterf vir hul getuienis tot die nasies as om geweld te pleeg (Op 7:14; 11:7). Insidente soos die veroordeling van die afkap van die slaaf se oor (Luk 22:50) en Paulus se bekering van sy gewelddadigheid (Hand 9:1; 13-16; vgl die bydrae van Van Houwelingen), bied praktiese voorbeelde van die Bybel se vredeskarakter. Selfs in die geval van Openbaring met sy gewelddadige materiaal, is hierdie vredesmateriaal opvallend teenwoordig. Die slot van Openbaring beeld 'n paradysagtige toestand van kosmiese, universele omvang aan. Die nuwe stad is die woonplek van God waar beskerming deur 'n stadsmuur onnodig is en waar op 'n inklusiewe manier, 'n nimmer-eindigende invloei van wêreldnasies plaasvind (Op 21:22-27; 22:1-2). In die stad is geen kwaad en geweld nie (o a Op 21:8; 22:15). God bring lyding tot 'n einde (Op 21:4). Reeds in die teenwoordigheid van hierdie motiewe word die plek van geweld verder belig.

\subsection{Groter verbande}

Volf (1996:291) het tereg daarop gewys dat die probleem van geweld nie deur die opstapeling van verse oor voorvalle van nie-geweld opgelos kan word nie. 
Die feit dat individuele tekste gewelddadig of nie-gewelddadig is, moet hermeneuties geweeg word. ${ }^{23}$ Ook O'Donovan (2003:1-3) het opgemerk dat vrede nie noodwendig die "antwoord" op geweld as 'n natuurlike bestaansvorm is nie - asof vrede en geweld twee ewe belangrike begrippe is nie. Hy beskou geweld as die indringer teenoor vrede wat die wesenlike van God se skepping is. Aan die ander kant het Deleuze byvoorbeeld Jesus se onselfsugtige offerande gesien as bloot net 'n voorbereiding vir God se groter gewelddadigheid in die eindtyd (vgl Volf1996:291) ${ }^{24}$. Hierdie opmerkking moet eksegetiese verder getoets word, veral omdat antwoorde hierop belangrike rigting sal gee aan die besinning oor die verhouding van geweld tot vrede, of, van vrede tot geweld.

Dit beteken prakties byvoorbeeld dat die rol van vrede in die Bybel na inhoud en funksie geëvalueer moet word, maar ook in breër verbande bedink word. Vanuit 'n hermeneutiese hoek is sekere insigte, hoewel eenvoudig, tog ter sake: Bybelse vrede beteken byvoorbeeld die afwesigheid van alle vorme van geweld en oorlog (bv Ps 120:6-7; Luk 14:32; Hand 7:26; 24:2; Luk 12:51; Op 6:3-4). Gelowiges word nie betrek in gewelddadige oorlogaksies soos in Ou-Testamentiese tekste nie, maar geweld word ook uitdruklik verwerp. Nog meer word gelowiges in navolging van Christus selfs aangesê om geweld as 'n las op hulle te neem. Hier is, by wyse van spreke, selfs sprake van 'n omhelsing van geweld (Hand 9:16). Om gelowig te wees, beteken om geweld van ander te verduur en toe te laat. ${ }^{25}$ Maar die tekste beweeg nog verder. Getuies word konkreet en ewe radikaal tot vyandsliefde verplig. Liefde vervang geweld en kenmerk die reaksie van gelowiges op gewelddadige aanslae. En, in 'n verdere dimensie, word gelowiges aktief aangemoedig om

\footnotetext{
${ }^{23}$ Volf (1996:291) wil spesifiek oor die tema nadink in teme van "what is described in the key junctures in the drama of Jesus Christ, notably the cross and second coming." Dit herinner ook aan soorgelyke motiewe waarmee Hays (1996) sy etiese analise doen, spesifiek ook ten opsigte van geweld.

${ }^{24}$ Deleuze se opmerking funksioneer binne 'n groter debat. Volf (1996:291) merk daarom op dat vir Deleuze, "the denial of self is the first step in the destruction of the self, both one's own self and that of another. Together they reinforce the system of judgment, which is a system of terror." Hierdie siening van Deleuze illustreer op 'n spesiale manier die belangrikheid van die debat oor geweld. Kyk ook die bespreking hier onder oor geweld en geregtigheid.

${ }^{25}$ Desjardins (1997:61) praat van geweld "that is to be embraced." Vgl hiermee ook Volf (1996:294) wat praat van die kruis (met verwysing na Milbank) as "a divine embrace of the deceitful and the unjust .... In an act of sheer grace, justice and truth would be suspended, and a reconciling embrace take place." Maar dit word, in die perspektief van Volf, gedoen juis om 'n nuwe wêreld van geregtigheid en waarheid tot stand te bring. Vir Volf word die siklus van geweld deur die offer van Jesus deurbreek. "I believe, instead, that the biblical texts narrate how God has necessarily used the sacrificial mechanism to remake the world into a place in which the need to sacrifice others could be eschewed - a new world of self-giving grace, a world of embrace." Hier blyk die invloed van Girard se denke op Volf.
} 
vrede as alternatief op 'n gewelddadige wêreld te soek. ${ }^{26}$ Dit sou uiteindelik 'n terugkeer tot 'n vredesbedeling beteken wat sterk lyk op die OuTestamentiese sjalom-voorstelling. Al hierdie dimensies verdien oorweging in die nadenke oor die verhouding van geweld tot sy teenpole (Desjardins 1997:16-61). ${ }^{27}$

Van Houwelingen het in sy eksegetiese bydrae tot hierdie bundel noukeurig uitgewys hoe Paulus na sy Damaskus-ervaring fisieke geweld sku en dit nie gebruik in die verspreiding van die evangelie nie, waarskynlik onder invloed van die Bergrede. Paulus word, in sy woorde, "een vechter met vreedzame middelen." Daarmee is ook groter verbande aangewys in resepsies binne die Nuwe Testament wat die stukrag van die evangelie se geweldlose karakter ondersteun. Dat Paulus, in Van Houwelingen se siening, sy latere lyding nie as straf vir sy gewelddadigheid sien nie, bevestig dat geweld vir Paulus nie 'n weerwraak-karakter het nie. Nog meer dergelike perspektiewe kom na vore in Van Aarde se bydrae waarin hy veronderstel dat Paulus 'n transformasie uit sy gewelddadigheid ondergaan het en waarin hy ondersoek wat alles tot die transformasie bygedra het. ${ }^{28}$ Ook Weren wys in sy versigtige analise op die groter verbande waarin geweld verstaan moet word: hoewel Jesus die owerspelige vrou deegliks as skuldig beskou en sy daarom eintlik 'n gewelddadige einde moet kry, word haar lot uiteindelik opgeweeg in terme van vergewing en barmhartigheid. Daarom kan sy vry uitgaan. Met hierdie opmerkings onderstreep Weren hoe nodig dit is om weer eens teologies na te dink oor die implikasies van vergifnis en barmhartigheid - wat albei sentrale motiewe in Bybelse tekste is. ${ }^{29}$ 'n Belangrike hermeneutiese filter word deur Matteus, wat origens dikwels van gewelddadigheid aangekla

\footnotetext{
${ }^{26}$ Dit is 'n belangrike insig wat deur Desjardins (1997:62) uitgespel word. "A double-edged exhortation emerges, then, from the New Testament: do not be violent toward others and do be willing to suffer the violence of others, following Jesus' example and that set by his earliest followers." Sy dubbele insigte moet egter, soos hier aangedui, met ander ewe geldige aspekte verbind word.

${ }^{27}$ Oor hierdie en ander aspekte van vrede in die Nuwe Testament, kyk De Villiers (2008) en die literatuur wat daar bespreek word.

${ }^{28}$ Die Pauliniese resepsies in hierdie bundel illustreer hoe die perspektiewe op Paulus se niegewelddadigheid, wat duidelik prominent is, afgeweeg moet word teen ander gewelddadige kante van sy tekste (bv in Galasiërs, soos Tolmie in sy presiese lees van die teks aangetoon het).

${ }^{29} \mathrm{Vgl} \mathrm{ook}$ sy bespreking van Matteus 25 (in Weren 2004), waarin die motief van barmhartigheid besonder sterk na vore kom - en dit binne 'n konteks waarin die eskatologiese straf ' $n$ tema is. Hierdie artikel toon ook hoedat die eindoordeel in al sy gewelddadigheid funksioneel gedrag in die hede bepaal - 'n hermeneutiese insig wat verdere aandag verdien in die bespreking van die rol van geweld.
} 
word, ${ }^{30}$ op die manier op geweld geplaas. Hermeneuties beteken dit dat moderne lesers deur noukeurige teks-analise dikwels verslete motiewe en simbole soos vergifnis en barmhartigheid weer nuwe lewe moet kan laat kry.

\subsection{Vrede in die resepsie van die Bybel}

Daar is ook 'n verdere filter of raam wat op geweldstekste pas. Dit is belangrik om die vroegste resepsies van die Bybelse tekste in gedagte te bly hou. Dit het te doen hoe sterk die vredesmotief by belangrike denkers in die vroeë resepsie-geskiedenis van die Nuwe Testament voorkom (Johnson 1999; vgl Bercott 1992:40-2 en die bespreking hierbo). As 'n dominante trajek bevestig dit dat so 'n sterk fokus soos dié van Hays (1996:335-7), hoewel eensydig, nie sonder aanknopingspunt in die Christelike tradisie is nie. Die niegewelddadige, anti-gewelddadige en vredesmateriaal speel 'n beduidende rol in die Nuwe Testament.

\subsection{Die vrede-geweld spanning}

Uit al hierdie opmerkings word dit duidelik dat daar in Bybelse tekste 'n spanning tussen geweld en vrede bestaan. Johnson (1999) se skerp resensie van Schwarz se boek (ook bespreek deur Van Henten in sy bydrae tot hierdie bundel) illustreer hierdie probleem vanuit 'n ander hoek. Hy het opgemerk hoedat die tradisie reeds van vroeg af met die lewegewende en destruktiewe aspekte van die Bybelse teks geworstel het. Irenaeus en Origines wou reeds bepaal op watter maniere die al te menslike teks lewegewend kon wees. Dit sou eensydig wees om insigte wat geweld bevraagteken, af te skaal of te ignoreer. Wat ook al die meriete van Johnson resensie is, sy punt is geldig dat daar inderdaad in die Bybelse tekste 'n spanningsvolle verhouding tussen geweld en "lewegewende" alternatiewe is. Die spanning kom volgens hom reeds in die Ou Testament voor, maar blyk verder in die algemeen ook uit die resepsie van die Ou Testament in die Nuwe Testament.

' $n$ Voorbeeld van hierdie posisie is te vind in die hantering van die heilige oorlog-tradisie in Openbaring (kyk die bydrae van De Villiers in die bundel; ook verder Giblin 1991:25-34 ${ }^{31}$ en Bauckham 1993:210-37). Die motief word daarin doelbewus van sy gewelddadige karakter ontneem. Openbaring as 'n Christelike oorlogsrol bevorder nie soos Qumran met sy

\footnotetext{
${ }^{30}$ Kyk die bespreking hierbo en die sterk kritiek van Desjardins (1997:69 - oor Matteus se felle anti-Joodsheid) en Carter (2005:102 - oor Matteus wat kapituleer voor imperiale geweld).

${ }^{31}$ Giblin het dit selfs nodig gevind om sy uitgebreide bespreking daaroor in sy inleiding as een van die twee oorheersende temas (saam met die eskatologie) op te neem.
} 
militaristiese messiaanse verwagtinge fisieke geweld nie. ${ }^{32}$ Die heiliges neem wel deel aan die eskatologiese oorlog, maar hul deelname is beperk tot martelaarskap deur hul getuienis en nie deur bloedvergieting nie (Bauckham 1993:210-237). Hier word die spanning in 'n sekere rigting opgelos.

Dit is egter net tot op 'n punt die geval. Openbaring word dikwels aangehaal in kritiek op absolute politieke magsaansprake (bv Rhoads 2005). Die Chileense Nuwe-Testamentikus, Richard (in sy bekende kommentaar van 1995 en ook weer in 2005) het aan die hand van Openbaring die verwoestende politieke en ekologiese gevolge van globalisering uitgespel, ${ }^{33}$ terwyl Westhelle (2005:198) daarop wys hoe bevrydend veral vroue Openbaring gevind het omdat dit hulle gehelp het om hulle misrabele omstandighede (hulle huishoudelike armoede, die alkoholisme van hul mans en die patriargale bestuur van hulle kampe) te analiseer en te herken as gesigte van die dier in Openbaring 13. In die geval van Pippin (2005), egter, word, soos hierbo aangehaal, die teks as gewelddadig teenoor vroue ondervind. Die boek bid vir haar geen ondersteuning vir die bevryding van vroue nie. In hierdie geval bly die spanning tussen geweld en vrede op 'n ander vlak voortbestaan. Dieselfde Bybelse dokument kan hoogs bevrydend in 'n situasie van geweld, maar terselfdertyd ontnugterend verknegtend ten opsigte van 'n ander kwessie bly.

Ten spyte daarvan dat die vredesmotief soms in die Nuwe Testament deur geweld verduister word, word dikwels aanvaar dat vrede die vertrekpunt bly om oor geweld te praat. Van Aarde het sy artikel in hierdie bundel vanuit hierdie hoek hanteer, naamlik dat by Paulus, die Christelike geloofsgemeenskap aan die hand van die kompakte formulas "in Christus," in die Here en "in die Gees" die bedding vorm waarbinne hy sy etiek oor geweld en toleransie ontwikkel het. Sy artikel integreer dus ook die gesprek oor geweld

\footnotetext{
${ }^{32}$ Kyk bv 1 QSb 5:24, 29; Bauckham (1993:214). Maar tog moet die ooreenstemminge van Nuwe-Testamentiese tekste met die ekstreme vilifikasie van Qumran-tekste nie uit die oog verloor nie, soos Frankfurter (2005:143) oortuigend aantoon.

${ }^{33}$ Kyk ook Richard (2005:164) waar hy Openbaring beskryf as 'n politieke teologie wat lesers aanspoor tot veral kulturele, etiese en spirituele verset. Thompson (1990:191) is een van die min uitleggers van Openbaring wat met insig uitgewys het hoe multi-dimensieel die boek se inhoude is en dus nie verskraal kan word tot blote sosiale, ekonomies of politieke geweld nie. Hy skryf "A myriad of qualities; behavioral traits; religious commitments; psychosocial understandings; and social, political interactions coalesce into a term like tribulation. At times it may gain impetus from social boundary (e.g., if a Christian is brought before the authorities), but the theme is more prominent in the religious committments and psychosocial understanding of the seer." Sy opmerkings fokus hier op die begrip "verdrukking," maar is ewe geldig vir 'n klomp ander begrippe in Openbaring - wat die multi-dimensionele karakter net nog verder beklemtoon. Dit bly 'n uitdaging om die populistiese, fundamentalistiese misbruik van Openbaring vir eindtyd berekenings én die ewe populistiese politieke verskraling van Openbaring tot 'n politieke program teen politieke instellinge te vermy.
} 
in 'n raamwerk waarin die vredesmotief die uitgangspunt vorm (kyk hieroor verder in die volgende afdeling).

Met hierdie opmerkings word dit duidelik dat die debat oor geweld 'n waaksaamheid en 'n sensitiwiteit vir al te menslike kante van Bybelse tekste vra. Dit word inderdaad 'n kritiese vraag na destruktiewe en lewegewend aspekte in Bybelse tekste wat teenoor mekaar afgeweeg moet word en waardeur die karakter van egte godsdiens geëvalueer word. Hoe dit gedoen is, in hierdie bundel en ook elders, moet kortliks verder aandag kry.

\title{
7. HANTERING VAN GEWELD IN DIE NUWE TESTAMENT
}

Ten slotte is dit nodig om te kyk op watter maniere geweld in die Nuwe Testament tot dusver in die Nuwe-Testamentiese wetenskap verduidelik of in 'n groter perspektief opgeneem word. Dit sal aan die hand van drie voorbeelde gedoen word.

\subsection{Nie-letterlike geweldstaal}

Dikwels word geweld in die Nuwe Testament simbolies gelees om dit as minder skadelik aan te bied. Dit gebeur veral waar God of gelowiges in die Bybel met geweld verbind word. Boring (1989:116 - kursivering toegevoeg) merk in sy wydgelese kommentaar op Openbaring op:

\begin{abstract}
None of the violence in the scenes of chapters 6-16 is literal violence against the real world; it is violence in a visionary scene of the future, expressed in metaphorical language (9:7!) .... The sword and fire by which the evil of the earth is judged (and even "tormented") are not literal swords and fire but metaphors for the cutting, searing word $(1: 16,11: 5)$.
\end{abstract}

Dit is sekerlik waar dat geweldstaal in die Nuwe Testament, soos hierbo verskeie kere uitgewys is, metafories, simbolies of nie-letterlik gelees moet word en dit is 'n benadering wat nog steeds geldig bly. ${ }^{34}$ Die probleem is dat sulke taal soms buitengewoon wraakgierig voorkom (bv Op 18:4-7), dat die veronderstelde simboliese aard daarvan by die minder onderskeidende leser verbygaan en onbedoelde destruktiewe konsekwensies het, soos hierbo opgemerk is, of dat wat simbolies effektief in een konteks is, kontra-produktief in 'n ander omgewing werk. Hier kan weer verwys word na die manier waarop in Openbaring die stereotipiese, patriargale uitbeelding van vroue as prostitute en bruide tot die voortgaande uitbuiting van vroue kan bydra (bv Pippin

\footnotetext{
${ }^{34}$ Kyk die interpretasie van Matteus 5:40 in die bydrae van Van Aarde in hierdie bundel vir verdere opmerking oor letterlike en nie-letterlike interpretasies.
} 
1992:96-103). ${ }^{35}$ In haar ouer essay oor geweld in Openbaring, het Collins (1983:747) tereg al gewaarsku oor die potensiaal van Openbaring se geweldstaal tot egte sielkundige en sosiale boosheid. Onlangs het Okoye (2005:118-120), weer opgemerk dat die impak van metaforiese, literêre geweldstaal in die Bybel nie onderskat moet word nie. Bybelse tekste wat op 'n poëtiese manier goddelike retribusie as seksuele geweld uitbeeld, het 'n fatale aantrekkingskrag en voed en vorm die kulturele verbeelding. Hy verwys na 'n opmerking van Miroslav Volf: "Die geweld van die goddelike woord is nie minder dodelik as die geweld van die letterlike woord nie."

\subsection{Regterlike en helende geweldstaal}

Goddelike, eskatologiese geweldstaal word verder dikwels geregverdig deur dit as 'n moreel legitieme verwerping van immorele geweld te verdedig. Hays (1996:334) het byvoorbeeld Jesus se reiniging van die tempel (Mark 11:19) as 'n profetiese bekeringsoproep beskryf. Jesus probeer nie om mag oor die tempel gewelddadig oor te neem nie, maar wil juis teen 'n onregverdige sisteem protesteer. "It is difficult to see how such a story can serve as a warrant for Christians to wage war and kill" (Hays 1996:335).

Nog sterker is God se gewelddadige oordeel oor die nasies uitgebeeld as kontra-geweld wat dus anders as provokatiewe geweld verstaan moet word. Dit wil vernietigende geweld weerstaan, ondermyn en destabiliseer. Dit inisieer nie geweld nie, maar volg op en reageer teen geweld. Weer eens is Openbaring 'n sleutelteks. Daarin kom die opponente se ekstreme gewelddadigheid herhaaldelik na vore (vgl die bydrae van De Villiers). Die vele opponente in Openbaring (die Jode, die Nikolaïete, die bose triade en die prostituut) verteenwoordig die "archetypically bad guys" (Wise 1996:150). Hulle reflekteer die patroon van die bose deur die tyd - Jerusalem, Sodom, Egipte, Babilon en Tirus as God se berugte teenstanders (Op 11). En hierdie omvattende "patroon" van geweld kom na vore in ekonomiese, politieke, morele en godsdienstige wandade waarin onbekeerlike verhard word. Die diepste kern van hierdie patroon word uitgedruk in terme van

onverdraagsaamheid, arrogansie, hardvogtigheid, profaniteit en minagting van menslike lewe - nie net van gelowiges nie, maar van "almal wat op aarde vermoor is" (Op 18:24). In die lig van sulke opmerkings word daarom dikwels daarop gewys dat God se woede nie te doen het met weerwraak nie, maar met 'n regterlike oordeel oor ekstreme vorme van onreg en geweld.

In noue samehang hiermee, word God se geweld origens ook gelegitimeer in terme van die helende uitkomste daarvan. In God se

\footnotetext{
${ }^{35}$ Kyk ook Frankfurter (2005:148), maar dan meer spesifiek oor hoe tekste oor martelaarskap latere lesers tot vergeldingsaksies dryf.
} 
komende, nuwe skepping in Openbaring, staan die boom van die lewe wat die volle jaar vrugte dra in die sentrum. Sy blare dien "tot genesing van die nasies" (Op 22:2-3). In hierdie teks word die metafoor van God as geneser van nasies uit die Ou Testament ontwikkel. Hul genesing kom nie maklik nie, want besmetting moet uitgesny word - vandaar die intense oordeelstonele in die res van die boek. Openbaring 18 sinspeel byvoorbeeld op Jeremia 6:14; 8:11 en veral 51:8-9 waar die volk opgeroep word om te vlug uit Babilon omdat die tyd van God se wraak aangebreek het: "Huil oor hom; gaan haal balsem vir sy pyn! Miskien sal hy gesond word" (Brueggemann 1996:254-5). Weer eens geld dan dat God se woede nie willekeurig of destruktief is nie, maar heling in gedagte het.

Brueggemann (1997:243-4) bied uiteindelik 'n nog dieper insig oor God se oordeel. "There is, to be sure, nothing innocent about Israel's rhetoric of violence and consequently there is nothing innocent about Yahweh. But then, neither Israel nor Yahweh pretends for one moment to live in a world of innocence." Dit is woorde wat in 'n sekere sin herinner aan Boer se opmerking, hierbo bespreek, dat hegemoniese geweld slegs deur politieke geweld tot 'n einde gebring kan word. Dit is opmerkings wat die vraag oproep of geweld onvermydelik is in die stryd teen geweld. Met ander woorde, kan sekere vorme van geweld op 'n sekere punt slegs deur kontra-geweld beëindig word? (vgl ook deel 3 hierbo).

Terwyl al hierdie argumente op die oog af 'n morele benadering weerspieël, het daar in onlangse tye ook hierin vrae na vore gekom. Hoe moet oordeel wat in die naam van God oor ander uitgespreek word, beoordeel word? Is oordeel, wat per definisie gewelddadig is, ooit moreel aanvaarbaar? Hoe moet gereageer word op Deleuze as hy skryf dat enige oordeel 'n sisteem van terreur is (Volf 1996:291, 299)? Carter (2005:99-102) verwys ook na God se oordeel in Matteus waarin God se geweld met imperiale geweld gekontrasteer word, maar beoordeel dit as 'n ironiese kapitulering voor en nabootsing van imperiale geweld (2005:102).

Dit is vrae wat Paul Decock in sy artikel in hierdie bundel soos volg formuleer (en waarvoor hy 'n insigryke oplossing voorstel):

Het huidige wereldbewustzijn is zeer gevoelig voor misbruik van macht en nodeloos geweld. Een "rechtvaardige oorlog" wordt in veel gemeenschappen aangevoeld als een oxymoron. Straf voor misdaden wordt eufemistisch voorgesteld als correctie door "correctieve diensten." Hoe kan men zich in deze tijd voorstellen dat God het project van de schepping juist door middel van oorlog en oordeel tot een goed einde zal brengen? Moet God het niet kunnen zonder geweld en zonder straf? 
Hiermee word die navorsing weereens met die wesenlik probleem oor legitieme geweld gekonfronteer, ${ }^{36}$ maar ook, soos van Henten aandui, met die verhouding tussen mag en geweld. Inderdaad, kan geweld, in die woorde van Decock in sy artikel, "skeppend" wees of is skeppende geweld 'n oxymoron?

\subsection{Vry van gewetensdwang}

Die bespreking van geweld moet voorts ook beoordeel word in die lig van die Bybelse motief dat die menslike respons tot God se heilsaanbod steeds 'n vrywillige karakter het en nie afgedwing word nie. Desjardins (1997:61) wys byvoorbeeld in die verband uit hoe die gelykenisse veronderstel dat mense 'n verantwoordelikheid het om op die uitnodiging te reageer. Ook in Pauliniese literatuur kry gemeentes ruimte tot eie besluitneming. Dejardins merk tereg op,

The New Testament constantly enourages its readers and listeners to open themselves to a new appreciation of their own needs and the needs of others. The Sermon on the Mount seeks this end plainly, whereas the parables perhaps achieve it best. "Be little ones" is the New Testament refrain: be forgiving and humble, open to treating every Christian as equal. Give people freedom to make up their own minds ... And do not forget the basic human needs of your Christian brothers and sisters (e. G. in James). These are all peace-promoting exhortations.

(Desjardins 1997:61)

Dit word bevestig deur die inklusiewe en universele karakter van die getuienis-taak in sulke boeke soos Handelinge, die Pauliniese literatuur en selfs Openbaring met sy prominente aandag aan die nasies se bekering (Op 9:20-21; 10:11; veral 14:6-7; Op 15:2-4; vgl Bauckham 1993:238-337; Marshall 2001:185-7). Terwyl dit in 'n sektariese sin sou kon beteken dat van die nasies verwag word om soos die eie groep te word, is die vraag of so 'n inklusiewe tendens nie die potensiaal het om sektariese denke te implodeer nie.

\section{SLOT}

In hierdie artikel is na aanleiding van die bydraes in hierdie bundel en in die lig van die debat oor geweld in die Nuwe-Testamentiese wetenskap, enkele hermeneutiese lyne vir die gesprek oor Bybelse geweld getrek. Dit het

\footnotetext{
${ }^{36}$ Kyk ook die belangrike en insigryke slot-opmerkings oor die noodsaaklike plek van geweld in Paulus se denke in Tolmie se bydrae tot hierdie bundel.
} 
duidelik geword dat hierdie gesprek op belangrike punte begin vordering toon, besonder omvattend is en heelwat dimensies oor geweld ontsluit het. Die debat is ook in vele opsigte uitdagend, want dit onthul miskien meer as ooit tevore die al te menslike gesig van die Bybel. Maar dit is 'n belangrike gesprek wat wêreldwyd besonder aktueel is.

Daar is duidelike verskuiwings in die debat, in die sin dat Bybelse tekste en gelowiges nou ook as plegers van geweld beskou word en dat geweld nie maar net nog 'n lastige, sekondêre aspek van die NuweTestamentiese tekste is nie, maar hierdie boodskap selfs by tye verduister. Van Henten wys daarom tereg in sy bydrae daarop dat die Nuwe Testament konflikterende gesigspunte oor vrede en geweld bied. ${ }^{37}$

Die artikels in hierdie bundel en die navorsing oor hierdie konflikterende gesigspunte maak die vraag na die verhouding van vrede en geweld soveel dringender. In nadenke oor die kwessie, gaan dit nie net om eksegetiese insigte soos die verhouding tussen verbale retoriek in Matteus 23 en die vredesbeskrywing van Jesus in die Bergrede nie. Dit gaan egter ook oor wyer, hermeneutiese vrae - ten opsigte van die verstaan van Bybelse utisprake en ook uitsprake wat die etiek van die Nuwe Testamentiese wetenskap raak. Om maar enkeles te noem: wanneer, byvoorbeeld, oorskry navorsers etiese grense van billike interpretasie as hulle die skrywers van die Nuwe Testament se siening oor geweld onderspeel of hulle vredesuitsprake verdag maak $?^{38}$ Wat is norme van billike en dus van adekwate interpretasie van geweld en vrede in die Nuwe Testament? Watter rol speel anakronistiese sieninge van geweld of van vrede in die interpretasie van die Nuwe Testament?

Dit is belangrik om aan die hand van hermeneutiese insigte weer terug te gaan na die Bybel as formerende teks om dit met 'n geordende benadering te ondersoek. Terwyl die getuienis kompleks en die gesigspunte divers is, sal 'n kritiese ondersoek uiteindelik met groter vrug kan bepaal hoe geweld daardeur gevoed of veroordeel word. Wanneer die ondersoek met integriteit plaasvind, moet die debat self ook lewegewend wees.

\footnotetext{
${ }^{37}$ Vgl ook die opmerkings, vanuit 'n postmoderne konteks, van Pippin \& Aichele (1998:5-7) wat met hulle provokatiewe boek juis gevolge van die onderliggende ideologieë in die Bybel wil uitwys. "The essays in this book seek to uncover the effects of ideology on reading by exploring the other side (the under side, as it were) of the contemporary popular images of the kingdom of God: what the images leave unsaid, what they omit or distort, and so forth." Pippin \& Aichele (1998:7).

${ }^{38}$ Kyk hiervoor Johnson (1999), wat in meer detail hier onder bespreek sal word. Die bydrae van Nicklas elders in hierdie bundel is ook van groot belang om na te dink oor die implikasies van eksegetiese werk vir die integriteit van die Bybelwetenskap.
} 


\section{Literatuurverwysings}

Bauckham, R J 1993. The climax of prophecy: Studies on the Book of Revelation. Edinburgh: Clark.

Bercott, D W 1992. The early Christian view of war. Journal of Radical Reformation 1, 38-50.

Boer, R 1998. Ezekiel's axl, or anarchism and ecstacy, in Pippin, T \& Aichele, G, Violence, utopia and the Kingdom of God Fantasy and ideology in the Bible, 24-71. London: Routledge.

Boesak, A A 1987. Comfort and protest: The apocalypse from a South African perspective. Philadelphia, PA: Westminster.

Boring, M E 1989. Revelation. Interpretation. Louisville, KY: John Knox.

Carter, W 2005. Construction of violence and identities in Matthew's Gospel, in Matthews S \& Gibson E L (eds), Violence in the New Testament, 81108. New York: T \& T Clark.

Collins, A Yarbro 1983. Persecution and vengeance in the Book of Revelation, in D Hellholm (ed), Apocalypticism in the Mediterranean World and the Near East, 728-49. Tübingen: Mohr.

Collins, J J 2003. The zeal of Phinehas: The Bible and the legitimation of violence. JBL 122, 3-21.

De Villiers, P G R 2003. Religieuse ervaring as hermeneutiese beginsel in die interpretasie van Bybeltekste in die lig van die boek Openbaring. NGTT 44, 276-86.

De Villiers, P G R 2007. History, mysticism and ethics in Oecumenius: A hermeneutical perspective on the earliest extant Greek commentary on Revelation. SHE 33, 315-336.

De Villiers, P G R 2008. Towards a spirituality of peace. Acta Theologica Supple 11, 213-251.

Frankfurter, D 2005. Violence and religious formation: An afterword, in Matthews, E \& Gibson, E L (eds), Violence in the New Testament, 140152. New York: Clark.

Giblin, C H 1991. The Book of Revelation: The open book of prophecy. Good News Studies 34. Collegeville, MN: Liturgical.

Hays, R 1996. The moral vision of the New Testament: Community, cross, new creation: A contemporary introduction to New Testament ethics. New York: HarperSanFrancisco.

Hernández, J 2006. Scribal habits and theological influences in the Apocalypse. Tübigen: Mohr Siebeck. (WUNT 2.218.)

Johnson, L T 1999. How not to read the Bible. Commonweal. S.a.

Kaminsky, J 2003. Violence in the Bible. SBL Forum, n.p. Online:http://sblsite.org/Article.aspx?ArticlelD=159.

Knight, J 1999. Revelation. Readings: A new biblical commentary. Sheffield: Sheffield Academic Press.

Lüdemann, G 1997. The unholy in Holy Scripture: The dark side of the Bible. Louisville, KY: Westminster John Knox. 
Marshall, J W 2001. Parables of war: Reading John's Jewish Apocalypse. Waterloo: Wilfrid Laurier University Press.

Marshall, J W 2005. Collatoral damage: Jesus and Jezebel in the Jewish war, in S Matthews \& E L Gibson (eds), Violence in the New Testament, 3550. New York: Clark.

Matthews E \& Gibson, E L (eds) 2005. Violence in the New Testament. New York, London: Clark.

O'Donovan, O 2003. The just war revisited. Cambridge: Cambridge University Press.

Okoye, J C 2005. Power and worship: Revelation in an African perspective, in Rhoads, D (ed), From every people and nation: The Book of Revelation in intercultural perspective, 110-126. Minneapolis, MN: Fortress.

Pippin, T 1995. Death and desire: The rhetoric of gender in the apocalypse of John. Louisville, KY: Westminster John Knox.

Pippin, T 2005. The heroine and the whore: The apocalypse of John in feminist pespective, in Rhoads, D (ed), From every people and nation: The Book of Revelation in intercultural perspective, 127-145. Minneapolis, MN: Fortress.

Pippin, T \& Aichele, G (eds) 1998. Violence, utopia and the kingdom of God: Fantasy and ideology in the Bible. London: Routledge.

Rhoads, D 2005. From every people and nation: The Book of Revelation in intercultural perspective. Minneapolis, MN: Fortress.

Richard, P 1995. Apocalypse: A people's commentary on the Book of Revelation. Maryknoll, NY: Orbis.

Richard, P 2005. Reading the Apocalypse: Résistance, hope and liberation in Central America, in D Rhoads, From every people and nation: The Book of Revelation in intercultural perspective, 146-164. Minneapolis, $\mathrm{MN}$ : Fortress.

Royalty, R M 1998. The streets of heaven: The ideology of wealth in the apocalypse of John. Macon, GA: Mercer University Press.

Schüssler-Fiorenza, E 1986. The followers of the Lamb: Visionary rhetoric and social-political situation. Semeia 36, 123-146.

Schüssler-Fiorenza, E 1998. The Book of Revelation. Minneapolis, MN: Fortress.

Schwartz, R M 1997. The curse of Cain: The violent legacy of monotheism. Chicago, IL: University of Chicago Press.

Thompson, L L 1990. The Book of Revelation: Apocalypse and empire. New York: Oxford University Press.

Van der Dennenn, J M G. 1978. Hoe men de oorlog verdedigde. Speling 30, 61-71.

Van der Dennenn, J M G 1995. The origin of war. Groningen: Origin.

Weren, W 2004. Matteus 25: De minster der mijnen, in Maas, F, Maas, J \& Spronk, K (redd), De Bijbel spiritueel: Bronnen van geestelijk leven in die bijbelse geschriften, 535-542. Zoetermeer: Meinema \& Pelckmans. 
Westhelle, V 2005. Revelation 13: Between colonial and the postcolonial a reading from Brazil, in Rhoads, D (ed) 2005, From every people and nation: The Book of Revelation in intercultural perspective, 183-199. Minneapolis, MN: Fortress.

Wise, M, Abegg, M \& Cook, E, 1996. The Dead Sea scrolls: A new translation. San Francisco, CA: HarperSanfrancisco. 